\title{
17. MIOCENE SILICOFLAGELLATES FROM CHATHAM RISE, DEEP SEA DRILLING PROJECT SITE 5941
}

\author{
David Bukry, United States Geological Survey, Scripps Institution of Oceanography²
}

\begin{abstract}
Miocene silicoflagellates, dominated by Mesocena, are identified and correlated from Site 594 to other Deep Sea Drilling Project sites. Relative paleotemperature values from silicoflagellates at Site 594 are very low, supporting the evidence of the associated cold-water, low-diversity coccolith assemblages. The greatest abundances of Mesocena diodon nodosa yet recorded occur at Site 594, which is near the present Subtropical Convergence. Similarities in the ecostratigraphic records between Chatham Rise (Site 594) and the Falkland Plateau (Site 329) in the late Miocene indicate widespread events within the circum-Antarctic water mass.
\end{abstract}

\section{INTRODUCTION}

Neogene silicoflagellate assemblages occur in Hole 594 of Deep Sea Drilling Project (DSDP) Leg 90 on Chatham Rise, east of New Zealand. This is the southernmost of a series of holes drilled during Leg 90 between New Zealand and the equator, to provide a latitudinal transect for paleoceanographic analysis. Although sparse Eocene silicoflagellates occur in Hole 588C (Core 19) and Hole 592 (Core 40), the only Neogene silicoflagellate sequence is from Hole 594 (Cores 20 to 48). Most of the Leg 90 sections that were examined lack silicoflagellates. Site $594\left(45^{\circ} 31.41^{\prime} \mathrm{S}, 174^{\circ} 56.88^{\prime} \mathrm{E}\right.$, water depth $1204 \mathrm{~m}$ ) is presently under the Subantarctic Water Mass, just south of the Subtropical Convergence. Cold-water silicoflagellates and coccoliths that are identified from Hole 594 support a similar water-mass pattern in the late Miocene.

A quantitative investigation of the Neogene silicoflagellate assemblages from Hole 594 was done to permit comparison of the species array to those in similar and contrasting regions, such as Site 329 (Falkland Plateau, $50^{\circ} 39.31^{\prime} \mathrm{S}, 46^{\circ} 05.73^{\prime} \mathrm{W}$, water depth $1519 \mathrm{~m}$ ) and Site 285 (South Fiji Basin, $26^{\circ} 49.16^{\prime} \mathrm{S}, 175^{\circ} 48.24^{\prime} \mathrm{E}$, water depth $4658 \mathrm{~m}$ ) and to determine relative paleotemperature values. In addition to the autochthonous late Miocene silicoflagellates, the samples from Hole 594 contain persistent reworked Paleogene specimens. Eocene and Oligocene biosiliceous deposits of similar age are now well exposed on New Zealand, as in the Oamaru section (Mandra et al., 1973), and form a potential local source for reworked Paleogene silicoflagellates.

The systematic paleontology covers the species of genus Mesocena which predominate in most samples of the upper Miocene at Hole 594. The distribution of abundant occurrences of these species at other DSDP localities is analyzed to help explain the high abundances in Hole 594.

\footnotetext{
${ }^{1}$ Kennett, J. P., von der Borch, C. C., et al., Init. Repts. DSDP, 90: Washington (U.S. Govt, Printing Office). 92093.
}

\section{METHODS}

The samples taken aboard ship for shore-based silicoflagellate studies from the biosiliceous upper Miocene section of DSDP Site 594 were processed using $\mathrm{HCl}$ and $\mathrm{H}_{2} \mathrm{O}_{2}$ to help concentrate the silicoflagellates. Permanent strewn slides were prepared and a light microscope at $250 \times$ and $500 \times$ magnification, with mechanical stage translation, was used to systematically track the slide areas of $40 \times 22 \mathrm{~mm}$. Species were enumerated using a mechanical counter. All specimens encountered were recorded. Fragmented specimens were included in the counts by mental accumulation into whole specimens. Relative paleotemperature values (Ts) were calculated according to the scheme described by Bukry $(1981,1983)$.

Coccolith slides were prepared as standard whole-sediment smear slides as described in Bukry and Kennedy (1969). A light microscope with $250 \times$ and $500 \times$ magnification, rotating mechanical stage, and cross-polarized light was used to study the coccolith assemblages for identification of zones.

\section{ZONATION}

Several Distephanus speculum speculum zones representing partly different time intervals have been proposed for correlation of cool-water assemblages (Bukry, 1973b, 1976a; Ciesielski, 1975; Martini and Müller, 1976; Busen and Wise, 1977). In the late Miocene to early Pleistocene cool-water assemblages of the Northern Hemisphere, the $D$. speculum speculum zones are dominated by $D$. speculum speculum (Bukry, 1973b; Martini and Müller, 1976). At mid latitudes in the Northern Hemisphere, the Distephanus longispinus Zone and Distephanus pseudofibula Zone may also be recognized in the upper Miocene sediment below the $D$. speculum speculum Zone (Bukry, 1981). But the guide species for these zones are sparse in high-latitude assemblages from the Southern Hemisphere and limit recognition of these zones (Bukry, 1975c; Haq and Riley, 1976; specimens attributed to $D$. pseudofibula by Ciesielski, 1975, all show the morphology of $D$. speculum varians, a possibly cooler water phenotype). In the Southern Hemisphere a longer $D$. speculum speculum Zone has been identified by the first abundant occurrence of Mesocena circulus at the base (Bukry, 1975c, 1976a) and the first common occurrence of Distephanus octonarius at the top (Bukry, 1975c). The longer D. speculum speculum Zone in the Southern Hemisphere zone is used here, with the Miocene Mesocena circulus Subzone (Bukry, 
1975 c) identified by the common occurrences of Mesocena circulus and $M$. diodon nodosa (Fig. 1).

\section{RELATIVE PALEOTEMPERATURES (Ts)}

The percentages of cool- and warm-indicator taxa in a silicoflagellate assemblage have been used to indicate latitudinal paleotemperature trends (Bukry, 1981) and have permitted interregional paleotemperature comparisons between the Pacific and Atlantic oceans for coeval intervals (Bukry, 1984; in press). Late Miocene assemblages at Site 594 have low relative paleotemperature values (Ts $=0$ to 39 ) which are similar to the low values ( $\mathrm{Ts}=0$ to 57) that occur at Site 329 (see Bukry, 1976b), at similar latitude and in the same Subantarctic Water Mass, east of the Falkland Islands. By contrast, late Miocene values $(\mathrm{Ts}=85$ to 97 ) are distinctly warmer at Site 285 (Bukry, 1975b), in the Fiji Basin, to the north of Site 594.

Large abundances of Mesocena and Distephanus at Site 594 indicate very cool conditions for most of the examined sample levels. Warm-water Dictyocha and temperate Distephanus (quadrate) are common in only a few samples. The contrasting assemblages of Site 285 (Bukry, 1975b), nearer the equator, contain practically no Mesocena and only moderate numbers of Distephanus. Warm-water Dictyocha predominates $(>50 \%)$ throughout.

A comparison of relative paleotemperature values between the late Miocene samples from Site 594 and from North Pacific Site 581 (lat $43^{\circ} 55.62^{\prime} \mathrm{N}$, long $159^{\circ} 47.76^{\prime} \mathrm{E}$, depth $5476 \mathrm{~m}$ ) shows much higher values (warmer) for the North Pacific because of the predominance of the genus Dictyocha. Late Miocene values at Site 581 range from Ts $=52$ to 94 (Bukry and Monechi, in press), instead of the lower values of Ts $=0$ to 39 at Site 594, even though they are located at similar north $\left(44^{\circ}\right)$ and south $\left(45^{\circ}\right)$ latitudes. The great contrast between the assemblages is the predominance of Mesocena at Site 594, which reflects cool and nutrient-rich waters. At the eastern end of the North Pacific Current the relative paleotemperature values off the coast of California for late Miocene samples are also lower than at Site 581 and the assemblages contain more Mesocena (Bukry, 1981). Therefore, it is possible that the warm Kuroshio Current was intensified and advanced farther north during the late Miocene, enhancing the productivity of Dictyocha over Mesocena at Site 581. Late Quaternary assemblages in the area of Site 581 contain cool-water Distephanus octangulatus (Ling, 1980; Bukry and Monechi, in press).

\begin{tabular}{|c|c|c|c|c|}
\hline \multirow{2}{*}{ Age } & \multicolumn{2}{|c|}{ Northern Hemisphere } & \multicolumn{2}{c|}{ Southern Hemisphere } \\
\cline { 2 - 5 } & Legs 18 and 38 & Leg 63 & Leg 29 & Leg 36 \\
\hline Quaternary & - & - & - & D. speculum A \\
\cline { 5 - 5 } Pliocene & D. speculum & D. speculum & & D. speculum B \\
\cline { 5 - 5 } late Miocene & - & D. speculum & $\begin{array}{c}\text { D. speculum } \\
\text { M. circulus } \\
\text { Subzone }\end{array}$ \\
\cline { 3 - 4 } & & - & - & - \\
\cline { 3 - 5 } & & &
\end{tabular}

Figure 1. Comparison of age ranges for various Distephanus speculum zones from Deep Sea Drilling Project Legs.
This poleward heat transfer (Csanady, 1984) by the warmwater mass in the Kuroshio Current might be linked to overall cooling in the late Miocene. There are advected cool-water pulses recorded in the late Miocene of the central equatorial Pacific Hole 572D (Bukry, in press) and a general North Pacific cooling has been described (Keller, 1981). But there is a notable lack of Mesocena in the samples with cool-water pulses at the equatorial $\mathrm{Pa}$ cific hole ( $\mathrm{Ts}=18,30,32$, and 36). Thus the Mesocena abundances for Site 594, which yield low Ts values, result from both cool temperature and rich nutrient levels. Although better time scales will be needed to make coeval comparisons, the distinctive silicoflagellate assemblage of Site 594 represents an important new reference for analysis of silicoflagellate ecostratigraphy in the Pacific.

Diatom chronostratigraphic correlations (Denticula hustedtii Zone) of DSDP Sites 158, 329, 470, 472, 572, 581, and 594 (J. A. Barron, written communication, 1984) were used to make a preliminary check of silicoflagellate Ts trends for the early late Miocene. The sampling array in the Initial Reports is inadequate for detailed silicoflagellate comparisons, but similar, consistent low Ts values occur at Sites 173, 329, and 594, where cool or transitional waters probably occurred in the late Miocene. The only changing trend observed for the interval was one of the declining Ts values at the $\mathrm{Pa}$ cific equatorial Site 158 (Ts $=92$ to 63) and Site 572 (Ts $=96$ to 36 ).

The four silicoflagellate samples from Cores 594-23 to $594-25$ ( 214 to $228 \mathrm{~m}$ ) occur in the interval assigned to the late Miocene cool-water Thalassiosira antiqua Zone by Ciesielski (J. A. Barron, written communication, 1984). The Ts values are very low (Ts $=2$ or 3 ) except at the bottom of this interval $(\mathrm{Ts}=30$ ) in Sample 594-25-2, $8-9 \mathrm{~cm}$. A comparison of the same diatom zone at offshore California Sites 469 and 470 shows that the coolest value is $\mathrm{Ts}=27$ and the warmest $\mathrm{Ts}=61$. Farther south, off Baja California at Site 472 , warmer values occur, Ts $=58$ to 94 . This zone was not used for Site 581 and was not cored at Site 329. The coeval interval according to diatoms at northwest Pacific Site 581 is in Cores 581-5 to 581-6; at equatorial Pacific Hole 572D it is in Cores 572D-6 to 572D-11 (J. A. Barron, verbal communication, 1984). At both locations there is a general warming upward through the interval. Maximum Ts values at Site $581(\mathrm{Ts}=96)$ are higher than at Hole 572D $(\mathrm{Ts}=82)$, but minimum values are more disparate, with a minimum of Ts $=32$ for Hole 572D and Ts $=79$ for Site 581 . The exceptionally cold conditions at Site 594 appear to have persisted through the late Miocene, according to the relative paleotemperature values of silicoflagellates, correlated by diatom zonation.

\section{COMPARISON OF MESOCENA OCCURRENCES}

Mesocena circulus s. ampl. is most numerous at oceanic locations where cool-water currents or upwelling are most intense. Comparison of peak abundances at DSDP sites shows generally higher numbers at higher latitudes but equatorial abundances up to $34 \%$ at Site 157 show that the local cool, nutrient-rich waters of the Peru Current determine the productivity of $M$. circulus s. ampl. 
Actual latitude is too general a guide. Other fairly high abundances at low latitudes (Table 1) are noted for Holes 321 and 572A, which are also influenced by the Peru Current. In the South Atlantic, the cool nutrient-rich upwelled waters at the Walvis Ridge account for the relatively high $19 \%$ abundance of $M$. circulus $\mathrm{s}$. ampl. at Site 362. At high-latitude Site 594 the highest value of $95 \%$ follows moderate values of $28 \%$.

A comparison of the maximum abundance for $M$. diodon nodosa s. ampl. in the Atlantic and Pacific oceans shows similar maximum values near Ts $=40$ (Table 2), except for Site 594. As with $M$. circulus s. ampl., data are more numerous for the Pacific Ocean. Comparison of the relative timing of the maximum abundances be-

Table 1. Maximum abundance (percent) of Mesocena circulus s. ampl. recorded from Deep Sea Drilling Project (DSDP) and Experimental Mohole (EM) coring locations in the Pacific and Atlantic oceans, arranged from north to south.

\begin{tabular}{|c|c|c|c|c|}
\hline $\begin{array}{l}\text { Site or } \\
\text { Hole }\end{array}$ & Latitude & Abundance & Age & Total range \\
\hline \multicolumn{5}{|c|}{ Pacific Ocean } \\
\hline $433 \mathrm{~A}$ & $44^{\circ} 46.60^{\prime} \mathrm{N}$ & $\mathrm{x}$ & - & $\begin{array}{l}\text { I. Miocene to Pliocene or } \\
\text { Pleistocene }\end{array}$ \\
\hline 581 & $43^{\circ} 55.62^{\prime} \mathrm{N}$ & 7 & 1. Miocene & I. Miocene \\
\hline 580 & $41^{\circ} 37.47^{\prime} \mathrm{N}$ & 34 & i. Miocene & I. Miocene \\
\hline 303 & $40^{\circ} 48.50^{\prime} \mathrm{N}$ & 7 & $\begin{array}{l}\text { I. Miocene or e. } \\
\text { Pliocene }\end{array}$ & $\begin{array}{l}\text { m. or I. Miocene to 1. Miocene } \\
\text { or e. Pliocene }\end{array}$ \\
\hline 173 & $39^{\circ} 57.71^{\prime} \mathrm{N}$ & 3 & $\begin{array}{l}\text { m. Miocene and } \\
\text { Pleistocene }\end{array}$ & m. Miocene to Pleistocene \\
\hline 464 & $39^{\circ} 51.64^{\prime} \mathrm{N}$ & 24 & e. Pliocene & L. Miocene to e. Pleistocene \\
\hline 304 & $39^{\circ} 20.27^{\prime} \mathrm{N}$ & 17 & $\begin{array}{l}\text { 1. Miocene or e. } \\
\text { Pliocene }\end{array}$ & $\begin{array}{l}\text { I. Miocene to I. Miocene or e. } \\
\text { Pliocene }\end{array}$ \\
\hline $579 \mathrm{~A}$ & $38^{\circ} 37.61^{\prime} \mathrm{N}$ & 26 & e. Pliocene & e. and $\mathrm{I}$. Pliocene \\
\hline 310 & $36^{\circ} 52.11^{\prime} \mathrm{N}$ & 20 & I. Pliocene & I. Miocene to Pleistocene \\
\hline 466 & $34^{\circ} 11.46^{\prime} \mathrm{N}$ & 13 & Pleistocene & Pleistocene \\
\hline 469 & $32^{\circ} 37.00^{\prime} \mathrm{N}$ & 74 & 1. Miocene & $\begin{array}{l}\text { m. and } 1 \text {. Miocene to } 1 \text {. } \\
\text { Miocene or Pliocene }\end{array}$ \\
\hline 577 & $32^{\circ} 26.51^{\prime} \mathrm{N}$ & 22 & c. Pliocene & e. and I. Pliocene \\
\hline 470 & $28^{\circ} 54.46^{\prime} \mathrm{N}$ & 45 & $\mathrm{~m}$. Miocene & m. and 1 . Miocene \\
\hline $\mathrm{EM}$ & $28^{\circ} 00.58^{\prime} \mathrm{N}$ & 20 & $\begin{array}{l}\text { m. and } \mathrm{l} \text {. } \\
\text { Miocene }\end{array}$ & $\mathrm{m}$. and 1 . Miocene \\
\hline 472 & $23^{\circ} 00.35^{\prime} \mathrm{N}$ & 4 & 1. Miocene & 1. Miocene \\
\hline 495 & $12^{\circ} 29.78^{\prime} \mathrm{N}$ & 1 & $\begin{array}{l}\text { I. Miocene and } \\
\text { Pliocene }\end{array}$ & 1. Miocene and Pliocene \\
\hline 158 & $6^{\circ} 37.36^{\prime} \mathrm{N}$ & 5 & $\begin{array}{l}\text { m. and } 1 \text {. } \\
\text { Miocene }\end{array}$ & $\mathrm{m}$. and $\mathrm{I}$. Miocene \\
\hline 65.0 & $4^{\circ} 21.21 \cdot \mathrm{N}$ & $\mathrm{x}$ & - & 1. Miocene or Pleistocene \\
\hline $503 \mathrm{~A}$ & $4^{\circ} 04.04^{\prime} \mathrm{N}$ & 2 & 1. Pliocene & e. and $\mathrm{t}$. Pliocene \\
\hline 166 & $3^{\circ} 45.70^{\prime} \mathrm{N}$ & $x$ & - & Miocene or Pliocene \\
\hline $572 \mathrm{~A}$ & $1^{\circ} 26.09 \prime \mathrm{N}$ & 12 & e. Pliocene & e. Pliocene \\
\hline $572 \mathrm{D}$ & $1^{\circ} 26.09 ' \mathrm{~N}$ & 2 & m. Miocene & m. and I. Miocene \\
\hline 425 & $1^{\circ} 23.68^{\prime} \mathrm{N}$ & 2 & Pleistocene & Pleistocene \\
\hline 504 & $1^{\circ} 13.58^{\prime} \mathrm{N}$ & 6 & e. Pliocene & Pliocene and Pleistocene \\
\hline 157 & $1^{\circ} 45.70^{\prime} \mathrm{S}$ & 34 & e. Pliocene & I. Miocene to Pleistocene \\
\hline $157 \mathrm{~A}$ & $1^{\circ} 45.70^{\prime} \mathrm{S}$ & 1 & Pleistocene & Pleistocene \\
\hline 321 & $12^{\circ} 01.29^{\prime} \mathrm{S}$ & 13 & I. Pliocene & I. Pliocene \\
\hline 205 & $25^{\circ} 30.99^{\prime} \mathrm{S}$ & 6 & 1. Miocene & 1. Miocene \\
\hline 285 & $26^{\circ} 49.16^{\prime} \mathrm{S}$ & 1 & I. Miocene & 1. Miocene \\
\hline 278 & $56^{\circ} 33.42$ 'S & 48 & Pliocene & 1. Miocene or Pliocene \\
\hline 322 & $60^{\circ} 01.45$ 's & 4 & Pliocene & Pliocene \\
\hline \multicolumn{5}{|c|}{ Atlantic Ocean } \\
\hline 348 & $68^{\circ} 30.18^{\prime} \mathrm{N}$ & $\mathrm{x}$ & - & m. or I. Miocene \\
\hline 338 & $67^{\circ} 47.11^{\prime} \mathrm{N}$ & $\mathrm{x}$ & - & m. or 1. Miocene \\
\hline 407 & $63^{\circ} 56.32^{\prime} \mathrm{N}$ & 18 & Pliocene & Pliocene \\
\hline 408 & $63^{\circ} 22.63^{\prime} \mathrm{N}$ & 41 & m. Miocene & m. Miocene to Pliocene \\
\hline 555 & $56^{\circ} 33.70^{\prime} \mathrm{N}$ & 16 & m. Miocene & $\mathrm{m}$. and $\mathrm{l}$. Miocene \\
\hline $554 \mathrm{~A}$ & $56^{\circ} 17.40^{\prime} \mathrm{N}$ & 5 & 1. Miocene & 1. Miocene \\
\hline $552 \mathrm{~A}$ & $56^{\circ} 02.56^{\prime} \mathrm{N}$ & 4 & c. Pliocene & c. Pliocene \\
\hline 410 & $45^{\circ} 30.53^{\prime} \mathrm{N}$ & 4 & 1. Pliocene & 1. Pliocene \\
\hline 335 & $37^{\circ} 17.74^{\prime} \mathrm{N}$ & 4 & Pleistocene & Pleistocene \\
\hline 334 & $37^{\circ} 02.13^{\prime} \mathrm{N}$ & 4 & 1. Miocene & 1. Miocene \\
\hline $332 \mathrm{~B}$ & $36^{\circ} 52.72^{\prime} \mathrm{N}$ & $<1$ & i. Pliocene & i. Pliocene \\
\hline 333 & $36^{\circ} 50.45^{\prime} \mathrm{N}$ & 6 & i. Pliocene & I. Pliocene \\
\hline 397 & $26^{\circ} 50.70^{\prime} \mathrm{N}$ & 3 & 1. Pliocene & 1. Pliocene \\
\hline 362 & $19^{\circ} 45.45^{\prime} \mathrm{S}$ & 19 & 1. Pliocene & $\begin{array}{l}\text { Pliocene and Miocene or } \\
\text { Pliocene }\end{array}$ \\
\hline 328 & $49^{\circ} 48.67^{\prime} \mathrm{S}$ & 6 & 1. Miocene & 1. Miocene \\
\hline 329 & $50^{\circ} 39.31^{\prime} \mathrm{S}$ & 92 & Miocene & Miocene \\
\hline 327 & $50^{\circ} 52.28^{\prime} \mathrm{S}$ & 1 & Pleistocene & Miocene to Pleistocene \\
\hline
\end{tabular}

Note: Ages for the maximum abundance event and the range of $M$. circulus s. ampl. are also shown. $\mathrm{X}=$ present, but too sparse for accurate percentage.
Table 2. Maximum abundance (percent) of Mesocena diodon s. ampl. recorded from Deep Sea Drilling Project (DSDP) and Experimental Mohole (EM) coring locations in the Pacific and Atlantic oceans, arranged from north to south.

\begin{tabular}{|c|c|c|c|c|}
\hline $\begin{array}{l}\text { Site or } \\
\text { Hole }\end{array}$ & Latitude & Abundance & Age & Total range \\
\hline \multicolumn{5}{|c|}{ Pacific Ocean } \\
\hline 192 & $53^{\circ} 00.57^{\prime} \mathrm{N}$ & 6 & 1. Miocene & 1. Miocene \\
\hline $433 \mathrm{~A}$ & $44^{\circ} 46.60^{\prime} \mathrm{N}$ & $\mathrm{x}$ & - & m. Miocene to Pleistocene \\
\hline 581 & $43^{\circ} 55.62^{\prime} \mathrm{N}$ & 10 & I. Miocene & I. Miocene \\
\hline 303 & $40^{\circ} 48.50^{\prime} \mathrm{N}$ & 4 & $\begin{array}{l}\text { m. or I. Mio- } \\
\text { cene }\end{array}$ & m. Miocene to e. Pliocene \\
\hline 173 & $39^{\circ} 57.71^{\prime} \mathrm{N}$ & 4 & 1. Miocene & $\mathrm{m}$. and $\mathrm{I}$. Miocene \\
\hline 464 & $39^{\circ} 51.64^{\prime} \mathrm{N}$ & 6 & c. Pliocene & c. Pliocene \\
\hline 33 & $39^{\circ} 28.48^{\prime} \mathrm{N}$ & 8 & 1. Miocene & m. and I. Miocene \\
\hline 304 & $39^{\circ} 20.27^{\prime} \mathrm{N}$ & 1 & $\begin{array}{l}\text { 1. Miocene and } \\
\text { e. Pliocene }\end{array}$ & 1. Miocene to e. Pliocene \\
\hline $579 \mathrm{~A}$ & $38^{\circ} 37.61^{\prime} \mathrm{N}$ & 6 & e. Pliocene & e. Pliocene \\
\hline 310 & $36^{\circ} 52.11^{\prime} \mathrm{N}$ & 2 & Pliocene & Pliocene \\
\hline 466 & $34^{\circ} 11.46^{\prime} \mathrm{N}$ & 33 & c. Pliocene & c. Pliocene \\
\hline 469 & $32^{\circ} 37.00^{\prime} \mathrm{N}$ & 5 & 1. Miocene & $\mathrm{m}$. and 1 . Miocene \\
\hline 470 & $28^{\circ} 54.46^{\prime} \mathrm{N}$ & 20 & 1. Miocene & $\mathrm{m}$. and $\mathrm{l}$. Miocene \\
\hline EM & $28^{\circ} 00.58^{\prime} \mathrm{N}$ & 10 & m. Miocene & m. Miocene \\
\hline 472 & $23^{\circ} 00.35^{\prime} \mathrm{N}$ & 5 & m. Miocene & m. and 1 . Miocene \\
\hline 495 & $12^{\circ} 29.78^{\prime} \mathrm{N}$ & 1 & m. Miocene & m. Miocene \\
\hline 158 & $6^{\circ} 37.36^{\prime} \mathrm{N}$ & 8 & m. Miocene & m. and 1 . Miocene \\
\hline $503 \mathrm{~A}$ & $4^{\circ} 04.04^{\prime} \mathrm{N}$ & 40 & I. Miocene & 1. Miocene to 1. Pliocene \\
\hline $572 \mathrm{~A}$ & $1^{\circ} 26.09^{\prime} \mathrm{N}$ & 0 & - & e. Pliocene \\
\hline 572D & $1^{\circ} 26.09^{\prime} \mathrm{N}$ & 0 & - & m. and 1 . Miocene \\
\hline 504 & $1^{\circ} 13.58^{\prime} \mathrm{N}$ & 1 & 1. Miocene & 1. Miocene \\
\hline 157 & $1^{\circ} 45.70^{\prime} \mathrm{S}$ & 1 & 1, Miocene & 1. Miocene to Pleistocene \\
\hline 285 & $26^{\circ} 49.16^{\prime} \mathrm{S}$ & $<1$ & m. Miocene & m. Miocene \\
\hline 206 & $32^{\circ} 00.75^{\prime} \mathrm{S}$ & $\mathrm{x}$ & - & $\mathrm{m}$. and 1 . Miocene \\
\hline 281 & $47^{\circ} 54.84^{\prime} \mathrm{S}$ & 20 & I. Miocene & 1. Miocene \\
\hline 278 & $56^{\circ} 33.42^{\prime} \mathrm{S}$ & 16 & 1. Miocene & 1. Miocene or Pliocene \\
\hline 322 & $60^{\circ} 01.45^{\prime} \mathrm{S}$ & 6 & Pliocene & Pliocene \\
\hline 323 & $63^{\circ} 40.84^{\prime} S$ & $\mathrm{x}$ & m. Pliocene & m. Pliocene \\
\hline \multicolumn{5}{|c|}{ Atlantic Ocean } \\
\hline 348 & $68^{\circ} 30.18^{\prime} \mathrm{N}$ & $\mathrm{x}$ & $\begin{array}{l}\text { m. Miocene to } \\
\text { e. Pliocene }\end{array}$ & m. Miocene to e. Pliocene \\
\hline 338 & $67^{\circ} 47.11^{\prime} \mathrm{N}$ & 34 & m. Miocene & m. Miocene \\
\hline 407 & $63^{\circ} 56.32^{\prime} \mathrm{N}$ & $\mathrm{x}$ & e. Pliocene & e. Pliocene \\
\hline 408 & $63^{\circ} 22.63^{\prime} \mathrm{N}$ & 14 & 1. Miocene & m. Miocene to Pliocene \\
\hline 555 & $56^{\circ} 33.70^{\prime} \mathrm{N}$ & 1 & m. Miocene & m. Miocene \\
\hline $554 \mathrm{~A}$ & $56^{\circ} 17.40^{\prime} \mathrm{N}$ & 37 & I. Miocene & 1. Miocene \\
\hline 552 & $56^{\circ} 02.56^{\prime} \mathrm{N}$ & 22 & 1. Miocene & I. Miocene \\
\hline $552 \mathrm{~A}$ & $56^{\circ} 02.56^{\prime} \mathrm{N}$ & 1 & I. Miocene & 1. Miocene to e. Pliocene \\
\hline 334 & $37^{\circ} 02.13^{\prime} \mathrm{N}$ & $<1$ & 1. Miocene & 1. Miocene \\
\hline $391 \mathrm{~A}$ & $28^{\circ} 13.61^{\prime} \mathrm{N}$ & 3 & m. Miocene & m. Miocene \\
\hline $394 \mathrm{~A}$ & $28^{\circ} 11.70^{\prime} \mathrm{N}$ & 2 & m. Miocene & m. Miocene \\
\hline 358 & $37^{\circ} 39.31^{\prime} \mathrm{S}$ & $\mathrm{X}$ & 1. Miocene & 1. Miocene \\
\hline 328B & $49^{\circ} 48.67^{\prime} \mathrm{S}$ & $\mathrm{x}$ & 1. Pliocene & 1. Pliocene \\
\hline 329 & $50^{\circ} 39.31^{\prime} \mathrm{S}$ & 33 & I. Miocene & 1. Miocene \\
\hline 327 & $50^{\circ} 52.28^{\prime} \mathrm{S}$ & $<1$ & Pleistocene & Miocene to Pleistocene \\
\hline
\end{tabular}

Note: Ages for the maximum abundance event and the range of $M$. diodon s. ampl. are also shown. $\mathrm{X}=$ present, but too sparse for accurate percentage.

tween these two taxa shows that $M$. diodon nodosa s. ampl. typically precedes $M$. circulus s. ampl. At 17 localities compared, $M$. diodon nodosa s. ampl. has an earlier maximum abundance peak at 11 sites (DSDP $157,158,285,303,304,472,503 \mathrm{~A}, 504,579 \mathrm{~A}$, and 581, and EM site). The order is reversed at five sites (DSDP $173,310,278,469$, and 470). The general stratigraphic range of $M$. diodon nodosa s. ampl. is briefer and earlier than for $M$. circulus s. ampl. Site 594 does show the reverse relation in maximum abundances but the base of the section is not established. More significantly, the highest abundances of $M$. diodon nodosa ever recorded $(86 \%, 77 \%, 75 \%$, etc.) are in Cores $594-23$ through 594-30. This pre-eminence of $M$. diodon nodosa indicates a specialized condition for this area.

Previous studies from the Southern Ocean, off Antarctica (Ciesielski, 1975; Perch-Nielsen, 1975; Bukry, 1975c; Haq and Riley, 1976; Busen and Wise, 1977), have shown low and sporadic abundances except at one 
site (Site 329) where 2 to $33 \% M$. diodon nodosa occur. The location of Site 329 at $50^{\circ} 39^{\prime} \mathrm{S}$ latitude, at $1519 \mathrm{~m}$ water depth on the Falkland Plateau, is also analogous to Site 594, at $45^{\circ} 31.41^{\prime} \mathrm{S}$ and $1204 \mathrm{~m}$, east of New Zealand. Higher-latitude sites to the south (nearer Antarctica) lack $M$. diodon nodosa or have only sparse (1-3\%) occurrences. The highest abundances of $M$. diodon nodos $a$ at Sites 594 and 329 identify intensified activity at the Subtropical Convergence in the late Miocene. High abundance of $M$. diodon nodosa elsewhere may also signify convergence zone conditions.

\section{DSDP HOLE 594 COMPARED TO DSDP HOLE 329}

The presence of Mesocena triangula and reworked Paleogene silicoflagellates in samples from Cores 20 to 31 at Site 594 suggested a potential similarity and ecostratigraphic correlation to Site 329 , which was cored earlier on the Falkland Plateau. A comparison of quantitative silicoflagellate occurrences for Site 594 (Table 3) and Site 329 (Bukry, 1976b) demonstrates a sequence of similar events (Table 4). Three lower correlation events in the upper Miocene are the boundary between moderate (Ts $=26$ to 57$)$ and very low (Ts $=0$ to 9 ) relative paleotemperature values (Ts) and the bracketing by major and minor concentrations of Distephanus crux crux above and below. The middle three events are an increase of Paleogene reworked silicoflagellates, bracketed by concentrations of Mesocena circulus below and Dictyocha aspera clinata above. The final trio of correlation events includes a dominance reversal of $M$. diodon s. ampl. and $M$. circulus s. ampl. followed by the highest Ts values (Ts $=30$ and 10 ) above the lower part of the section, and finally the conjunction of $M$. triangula with $M$. quadrangula. These events are believed to represent interregional changes that are probably related to circum-Antarctic ocean circulation. Both drill sites lie within the present area of Subantarctic Water, south of the Subtropical Convergence (see Kennett, 1980, fig. 2) and just south of the Subantarctic Convergence (Burkov, 1966). Periods of major current scour may be recorded by the reworked Paleogene taxa at both areas. Similarities in temperature and nutrient changes account for the species correlations.

Some of the species events compared between the two sites did not prove to be sequentially correlative between the two regions. These included the local acmes of Dictyocha brevispina, D. fibula augusta, D. pentagona, Distephanus speculum minutus, and $D$. speculum speculum.

The similarity in the sequence of silicoflagellate events between Site 594, Cores 23 to 31, and Site 329, Cores 2 to 17 , suggests that the late Miocene age of Site 329 may be applied to Site 594 .

Shipboard identification of a fairly complete middle Miocene to early Pliocene sequence of coccolith Zones NN7/8, NN9, NN10, NN11, and NN12/14 for Cores 20 to 31 at Site 594 is not supported by shore-based examination of the section. The samples contain limited coolwater assemblages that lack all of the zonal guide species which define these numbered zones (Martini, 1971), including Discoaster kugleri, D. hamatus, D. quinque- ramus, and Amaurolithus tricorniculatus. Among the low-diversity, placolith-dominated assemblages, only a few contained coccolith species with ranges useful for stratigraphic correlation. Cores 26 and 29 contain sparse D. brouweri s. ampl. and D. bellus, and Cores 23 and 26 contain Triquetrorhabdulus rugosus which, together, indicate a probable late Miocene correlation of these cores, if the specimens are stratigraphically in place. Actually, there is a significant number of reworked $\mathrm{Pa}$ leogene species such as Chiasmolithus oamaruensis and Isthmolithus recurvus in these samples. Therefore, identification of coccolith zonal boundaries should be considered as tenuous and only a general late Miocene age is indicated.

\section{SUMMARY}

The main results of this initial study of silicoflagellates from Site 594 are summarized below.

1. Very high abundances of Mesocena diodon nodo$s a$ occur in the upper Miocene from Site 594, and may be a guide to convergence zone conditions.

2. A sequence of similar silicoflagellate events between Site 594 and Site 329 in the Atlantic suggest possible ecostratigraphic correlation throughout the circum-Antarctic water mass. The increase in Paleogene reworking at both sites shows timing for widespread scour and current activity.

3. Comparison of low relative paleotemperatures from Site 594 (lat. $45^{\circ} \mathrm{S}$ ) with high values at North Pacific Site 581 (lat. $44^{\circ} \mathrm{N}$ ) supports an intensified and more northerly warm Kuroshio Current in the North Pacific for the late Miocene. The late Quaternary flora just south of Site 581 yields low Ts values typical of cool water conditions.

4. Taxonomic distinction of M. circulus var. apiculata from M. dumitricae may be useful for paleoecological reconstructions, as the latter appears to be favored by cooler conditions.

\section{SYSTEMATIC PALEONTOLOGY OF GENUS MESOCENA EHRENBERG, 1843, FROM DSDP HOLE 594}

\section{Mesocena circulus (Ehrenberg) Ehrenberg \\ (Plate 3, Figs. 3-6)}

Dictyocha (Mesocena) circulus Ehrenberg, 1840, p. 208. Figured by Ehrenberg, 1854, pl. 19, fig. 44.

Mesocena circulus (Ehrenberg) Ehrenberg, 1844, p. 65.

Mesocena circulus (Ehrenberg), Mandra and Mandra, 1972, pl. 31, fig. 36.

Mesocena circula (Ehrenberg), Bukry and Foster, 1973 (in part), p. 828, pl. 5 , fig. 9.

Paradictyocha circulus (Ehrenberg) Dumitricà, 1973, p. 853, pl. 9, figs. 7-10.

Bachmannocena circulus (Ehrenberg) Locker, 1974, p. 636, pl. 2, fig. 11.

Mesocena circulus (Ehrenberg), Bukry, 1975a (in part), p. 718, pl. 2, fig. 4.

Paradictyocha circulus (Ehrenberg), Perch-Nielsen, 1975, p. 689, pl. 11, fig. 12.

Paradictyocha circulus (Ehrenberg) Dumitricǎ, Stradner and Bachmann, 1978 , p. 808 , pl. 2 , figs. $13-15$.

Remarks. For Site 594, Mesocena circulus is identified in a restricted sense which is limited to the morphology with numerous, small, irregular spines that was originally illustrated by Ehrenberg (1854) and repeated in lectotype material by Locker (1974). Previously, M. circulus $\mathrm{s}$. ampl. of some authors has also included long-spined specimens of M. dumitricae (see Bukry, 1975a; Busen and Wise, 1977) and speci- 
Table 3. Late Miocene silicoflagellates recorded as percentages from Cores 20 to 48 of Hole DSDP 594.

\begin{tabular}{|c|c|c|c|c|c|c|c|c|c|c|c|c|c|c|c|c|c|c|c|}
\hline Age & \multicolumn{17}{|c|}{ late Miocene } & \multicolumn{2}{|c|}{-} \\
\hline Zone & \multicolumn{17}{|c|}{ Distephanus speculum speculum Zone } & \multicolumn{2}{|c|}{-} \\
\hline Subzone & \multicolumn{17}{|c|}{ Mesocena circulus Subzone } & & \\
\hline Depth (m) & $\nsubseteq$ & \& & $\frac{\vec{N}}{N}$ & $\stackrel{\circ}{\bar{\lambda}}$ & สี & สి & $\tilde{\text { กे }}$ & $\bar{J}$ & 今 & సิ & ปิ & สี & $\widehat{s}$ & 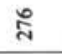 & $\overline{\mathbb{~}}$ & ๙ & \& & $\stackrel{\infty}{\dddot{\gamma}}$ & gे \\
\hline Sample & $\begin{array}{l}\hat{\alpha} \\
\text { ஸे } \\
\hat{\jmath}\end{array}$ & $\begin{array}{l}\hat{\omega} \\
\dot{N} \\
\hat{N}\end{array}$ & $\begin{array}{l}\hat{े} \\
\infty \\
\dot{n} \\
\dot{\tilde{n}}\end{array}$ & $\begin{array}{l}\hat{\alpha} \\
\infty \\
\tilde{j} \\
\dot{z}\end{array}$ & $\begin{array}{l}a \\
\dot{1} \\
\dot{n} \\
\dot{d}\end{array}$ & \begin{tabular}{l} 
iे \\
ஸें \\
\multirow{2}{*}{}
\end{tabular} & $\begin{array}{l}\hat{a} \\
\text { के } \\
\text { 今े }\end{array}$ & $\begin{array}{l}\text { के } \\
\dot{j} \\
\dot{d}\end{array}$ & $\begin{array}{l}\hat{i} \\
\infty \\
i \\
\stackrel{+}{+}\end{array}$ & 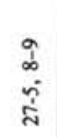 & 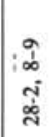 & 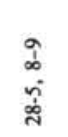 & $\begin{array}{l}\hat{a} \\
\text { o } \\
\hat{N} \\
\text { సे }\end{array}$ & 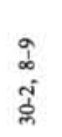 & $\begin{array}{l}\hat{1} \\
\infty \\
\dot{n} \\
0\end{array}$ & 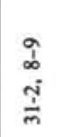 & $\begin{array}{l}a \\
\text { के } \\
\text { nे } \\
\frac{m}{m}\end{array}$ & 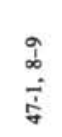 & 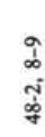 \\
\hline $\begin{array}{l}\text { Caryocha sp. } \\
\text { Dictyocha aspera aspera } \\
\text { D. aspera clinata s. ampl. } \\
\text { D. brevispina } \\
\text { D. fibula augusta }\end{array}$ & 1 & $\begin{array}{r}11 \\
1 \\
\end{array}$ & & & & & & $\begin{array}{l}1 \\
4 \\
1\end{array}$ & $\begin{array}{l}4 \\
. \\
\end{array}$ & 11 & & & & & & & & $\begin{array}{l}3 \\
1\end{array}$ & $\begin{array}{l}\mathbf{P} \\
\mathbf{P}\end{array}$ \\
\hline $\begin{array}{l}\text { D. fibula fibula } \\
\text { D. pentagona } \\
\text { D. pulchella } \\
\text { D. sp. aff. pulchella var. inflata } \\
\text { D. sp. (asperoid) }\end{array}$ & 1 & 3 & & 2 & $\begin{array}{l}2 \\
1\end{array}$ & $\begin{array}{r}3 \\
16 \\
7\end{array}$ & & 1 & $\begin{array}{l}9 \\
2\end{array}$ & 6 & 1 & $\begin{array}{l}4 \\
1\end{array}$ & $\begin{array}{l}1 \\
4\end{array}$ & & & $\begin{array}{l}1 \\
1\end{array}$ & $\begin{array}{l}2 \\
2\end{array}$ & $\begin{array}{r}25 \\
3\end{array}$ & $\begin{array}{l}\mathbf{P} \\
\mathbf{P}\end{array}$ \\
\hline $\begin{array}{l}\text { D. sp. (fibuloid) } \\
\text { Distephanus crux crux } \\
\text { D. frugalis } \\
\text { D. polyactis crassus } \\
\text { D. pseudofibula }\end{array}$ & 1 & 5 & 2 & 1 & $\begin{array}{l}1 \\
1\end{array}$ & $\begin{array}{l}7 \\
1\end{array}$ & & 5 & $\begin{array}{l}1 \\
1\end{array}$ & & 2 & 1 & $\begin{array}{l}1 \\
5\end{array}$ & 2 & 12 & $\begin{array}{l}1 \\
4\end{array}$ & $\begin{array}{l}2 \\
66\end{array}$ & $\begin{array}{r}5 \\
32\end{array}$ & $\begin{array}{l}\mathbf{P} \\
\mathbf{P}\end{array}$ \\
\hline $\begin{array}{l}\text { D. quinquangellus } \\
\text { D. speculum diommata } \\
\text { D. speculum minutus } \\
\text { D. speculum speculum } \\
\text { D. speculum triommata }\end{array}$ & $\begin{array}{r}2 \\
67 \\
24\end{array}$ & $\begin{array}{r}2 \\
8 \\
43\end{array}$ & $\begin{array}{r}1 \\
13\end{array}$ & $\begin{array}{r}1 \\
18\end{array}$ & $\begin{array}{r}1 \\
76\end{array}$ & 16 & 23 & $\begin{array}{l}1 \\
4 \\
1\end{array}$ & $\begin{array}{l}1 \\
6\end{array}$ & 30 & 11 & 9 & 27 & 1 & 1 & 1 & & & $\mathbf{P}$ \\
\hline $\begin{array}{l}\text { D. xenus } \\
\text { Mesocena circulus } \\
\text { M. circulus var. apiculata } \\
\text { M. circulus var. apiculata (knobby) } \\
\text { M. dumitricae }\end{array}$ & 1 & $\begin{array}{r}23 \\
1\end{array}$ & & 1 & 14 & $\begin{array}{l}22 \\
19\end{array}$ & 1 & $\begin{array}{r}18 \\
4\end{array}$ & $\begin{array}{r}2 \\
24 \\
\end{array}$ & 16 & 8 & 30 & 14 & $\begin{array}{r}61 \\
4\end{array}$ & 1 & $\begin{array}{r}94 \\
1 \\
1 \\
\end{array}$ & $\begin{array}{c}24 \\
4\end{array}$ & 31 & \\
\hline $\begin{array}{l}\text { M. sp. cf. diodon borderlandensis } \\
\text { M. diodon nodosa } \\
\text { N. diodon nodosa (circular) } \\
\text { M. diodon nodosa (oblate) } \\
\text { M. quadrangula }\end{array}$ & 3 & $\begin{array}{l}3 \\
1\end{array}$ & $\begin{array}{r}70 \\
1 \\
2 \\
2 \\
\end{array}$ & 77 & 4 & 9 & 75 & 59 & $\begin{array}{r}1 \\
51 \\
1\end{array}$ & $\begin{array}{r}29 \\
9\end{array}$ & $\begin{array}{r}78 \\
1\end{array}$ & $\begin{array}{l}44 \\
14\end{array}$ & $\begin{array}{r}38 \\
8 \\
3\end{array}$ & $\begin{array}{r}29 \\
2\end{array}$ & 86 & 1 & & & $\mathbf{P}$ \\
\hline $\begin{array}{l}\text { M. triangula } \\
\text { M. triodon }\end{array}$ & & & 9 & & & & & 1 & & & $\begin{array}{l}1 \\
1 \\
\end{array}$ & & & 1 & & & & & \\
\hline $\begin{array}{l}\text { Reworked } \\
\text { Corbisema apiculata } \\
\text { C. sp. cf. C. glezerae } \\
\text { C. hastata globulata } \\
\text { C. hastata hastata } \\
\text { C. inermis }\end{array}$ & & $\mathrm{x}$ & & & $\mathrm{x}$ & $x$ & $\mathrm{x}$ & $\begin{array}{l}\mathrm{X} \\
\mathrm{x}\end{array}$ & & $\mathrm{x}$ & & $\mathrm{x}$ & & & $\mathrm{x}$ & $\begin{array}{l}\mathrm{x} \\
\mathrm{x} \\
\mathrm{x} \\
\mathrm{x}\end{array}$ & $\mathrm{x}$ & $\mathrm{x}$ & $x$ \\
\hline $\begin{array}{l}\text { C. triacantha s. ampl. } \\
\text { C. spp. } \\
\text { Dictyocha deflandrei completa } \\
\text { D. sp. (asperoid) } \\
\text { D. sp. (fibuloid) }\end{array}$ & & $\begin{array}{l}x \\
x\end{array}$ & & $\mathrm{x}$ & $\begin{array}{l}\mathrm{x} \\
\mathrm{x} \\
\mathrm{x}\end{array}$ & $\mathrm{x}$ & $\mathrm{x}$ & $\mathrm{x}$ & $\begin{array}{l}x \\
x\end{array}$ & $\mathrm{x}$ & & & $\mathrm{x}$ & & $\begin{array}{l}\mathrm{x} \\
\mathrm{x}\end{array}$ & $\mathrm{x}$ & & $\begin{array}{l}x \\
x\end{array}$ & \\
\hline $\begin{array}{l}\text { Mesocena apiculata apiculata } \\
\text { M. apiculata curvata } \\
\text { M. apiculata glabra } \\
\text { Naviculopsis aspera } \\
\text { N. biapiculata }\end{array}$ & & $\mathrm{x}$ & & & $\mathrm{x}$ & $\mathrm{x}$ & $\mathrm{x}$ & $\begin{array}{l}\mathrm{x} \\
\mathrm{x} \\
\mathrm{x}\end{array}$ & $\begin{array}{l}\mathrm{X} \\
\mathrm{x} \\
\end{array}$ & $\mathrm{x}$ & $\mathrm{x}$ & & $\mathrm{x}$ & $\mathrm{x}$ & $\mathrm{x}$ & $\mathrm{x}$ & $\mathrm{x}$ & $x$ & $\mathrm{x}$ \\
\hline $\begin{array}{l}\text { N. sp. aff. } N \text {. biapiculata } \\
\text { N. constricta } \\
\text { N. eobiapiculata } \\
N \text {. sp. ff. } N \text {. trispinosa } \\
\text { Naviculopsis spp. }\end{array}$ & $\mathrm{x}$ & $\begin{array}{l}\mathrm{X} \\
\mathrm{X} \\
\mathrm{X}\end{array}$ & $\begin{array}{l}\mathrm{X} \\
\mathrm{X}\end{array}$ & $\mathrm{x}$ & $\mathrm{x}$ & $\mathrm{x}$ & & $\mathrm{x}$ & $\begin{array}{l}\mathrm{X} \\
\mathbf{Q}\end{array}$ & & $\mathrm{x}$ & $\$$ & $\begin{array}{l}x \\
x\end{array}$ & & $\mathrm{x}$ & $\begin{array}{l}\mathrm{x} \\
\mathrm{x} \\
\mathrm{x}\end{array}$ & & $\otimes$ & $\mathrm{x}$ \\
\hline $\begin{array}{l}\text { Reworked diatoms } \\
\text { Rocella gelida } \\
\text { R. schraderi }\end{array}$ & & $\mathrm{x}$ & & & $\mathrm{x}$ & $\begin{array}{l}X \\
X\end{array}$ & & & $\mathrm{x}$ & & $\mathrm{x}$ & $\mathrm{x}$ & $\mathrm{x}$ & $\mathrm{x}$ & & $\begin{array}{l}\mathrm{X} \\
\mathrm{x}\end{array}$ & $\mathrm{x}$ & & $\begin{array}{l}x \\
x\end{array}$ \\
\hline Total specimens (plus reworked) & $\begin{array}{r}100 \\
\text { (1) }\end{array}$ & $\begin{array}{l}103 \\
(25)\end{array}$ & $\begin{array}{r}100 \\
(2)\end{array}$ & $\begin{array}{r}100 \\
(2)\end{array}$ & $\begin{array}{r}100 \\
(7)\end{array}$ & $\begin{array}{l}100 \\
(10)\end{array}$ & $\begin{array}{r}100 \\
(3)\end{array}$ & $\begin{array}{r}100 \\
(7)\end{array}$ & $\begin{array}{l}201 \\
\text { (11) }\end{array}$ & $\begin{array}{r}200 \\
(3)\end{array}$ & $\begin{array}{r}200 \\
(4)\end{array}$ & $\begin{array}{r}200 \\
(2)\end{array}$ & $\begin{array}{r}100 \\
(4)\end{array}$ & $\begin{array}{r}200 \\
(3)\end{array}$ & $\begin{array}{r}100 \\
(5)\end{array}$ & $\begin{array}{l}200 \\
(31)\end{array}$ & $\begin{array}{l}50 \\
(4)\end{array}$ & $\begin{array}{l}100 \\
(11)\end{array}$ & $\begin{array}{l}19 \\
\text { (7) }\end{array}$ \\
\hline Paleotemperature value & 2 & 17 & 2 & 2 & 3 & 30 & 0 & 12 & 17 & 17 & 2 & 6 & 9 & 1 & 6 & 5 & 39 & 50 & - \\
\hline
\end{tabular}

Note: $\mathrm{X}=$ presence of reworked specimens; $=$ numerically predominant. ${ }^{*}=$ recorded after counts. $\mathrm{P}=$ too sparse for percent. 
Table 4. Matching silicoflagellate events between Site 594, east of New Zealand, and Site 329, east of the Falkland Islands, both within the present Subantarctic Water Mass.

\begin{tabular}{|c|c|c|}
\hline Silicoflagellate event & $\begin{array}{l}\text { Core or Section } \\
\text { at Site } 594\end{array}$ & $\begin{array}{l}\text { Core } \\
\text { at Site } 329\end{array}$ \\
\hline $\begin{array}{l}\text { Mesocena triangula and } M \text {. quadrangula } \\
\text { conjunction }\end{array}$ & 23 & 2 \\
\hline $\begin{array}{l}\text { Highest relative paleotemperature (Ts) } \\
\text { above the basal interval }\end{array}$ & $25-2$ & 4 \\
\hline $\begin{array}{l}\text { Coincident decline of } M \text {. diodon s. } \\
\text { ampl. and concentration of } \\
M \text {. circulus s. ampl. }\end{array}$ & $25-2$ and $25-5$ & 8 and 9 \\
\hline $\begin{array}{l}\text { Dictyocha aspera clinata s. ampl. } \\
\text { concentration }\end{array}$ & $26-4$ and $27-2$ & 11 and 12 \\
\hline Increase in Paleogene reworking & $27-2$ & 15 \\
\hline $\begin{array}{l}\text { Mesocena circulus } \mathrm{s} \text {. ampl. concentra- } \\
\text { tion }\end{array}$ & $30-2$ & 14 \\
\hline $\begin{array}{l}\text { Distephanus crux crux minor concentra- } \\
\text { tion }\end{array}$ & $30-5$ & 15 \\
\hline $\begin{array}{l}\text { Major reduction in relative paleotemper- } \\
\text { ature values (Ts) }\end{array}$ & $31-5$ to $31-2$ & 17 to 16 \\
\hline $\begin{array}{l}\text { Distephanus crux crux major concentra- } \\
\text { tion }\end{array}$ & $31-5$ & 17 \\
\hline
\end{tabular}

mens of M. circulus var. apiculata (see Bukry and Foster, 1973). Although the small spines of $M$. circulus may lie in the plane of the ring, they may also have variable positions along the outer periphery of the ring. The inner circumference lacks spines.

According to a subsequent designation by Loeblich et al. (1968), Mesocena? octogona is the type species for genus Mesocena. Previous designations of $M$. circulus or $M$. elliptica as type species could not be accepted by Loeblich et al. (1968) because they were not taken from the paper in which the genus name was defined. The simplistic illustration of $M$.? octogona could ambiguously represent several silica bodies. And its Holocene age separates it in time from all other taxa classified in Mesocena (Paleocene to mid Pleistocene). Locker's (1974) reexamination of Ehrenberg materials purports to reillustrate the holotype of M.? octogona and shows that it is the basal ring of Octactis. This is reasonable on the basis of the morphology and age of the specimen. Therefore, the status of the name Mesocena is in doubt; parenthetically, so is the status of Octactis. The other available species for Mesocena in the Ehrenberg publication, M.? heptagona, is simply a polymorph of M.? octogona. Mesocena circulus (Ehrenberg) Ehrenberg $(1844$, p. 65$)$ appears to be the next best choice if the name Mesocena, with 140 years of continuous usage, is to be retained. If Mesoce$n a$ were not conserved, then Bachmannocena of Locker (1974) could be substituted.

For this publication, the name Mesocena is retained for silicoflagellate skeletons composed of a single ring, with or without spines of various sizes and orientations. This includes the widely reported forms $M$. circulus and $M$. circulus var. apiculata among others. Resolution of the Mesocena problem will have to treat Bachmannocena, Paradictyocha, and Septamesocena, also.

\section{Mesocena circulus var. apiculata Lemmermann}

(Plate 2, Figs. 3-7; Plate 3, Figs. 1, 2)

Mesocena circulus var. apiculata Lemmermann, 1901, p. 257, pl. 10, figs. $9,10$.

Mesocena circulus Ehrenberg, Martini and Müller, 1976, p. 872, pl. 4, figs. 7,8 .

Mesocena circulus var. apiculata Lemmermann, Ling, 1972, p. 176, pl. 28, figs. 7,8 .

Mesocena circula (Ehrenberg), Bukry and Foster, 1973 (in part), p. 828, pl. 6, fig. 1.

Paradictyocha apiculata (Lemmermann), Perch-Nielsen, 1975, p. 689, pl. 11, figs. 14, 15 .

Mesocena circulus apiculata (Lemmermann) Ling, 1977, p. 214, pl. 2, fig. 24.

Remarks. The moderate-length spines of Mesocena circulus var. apiculata are equal to or longer than those on $M$. circulus and are more regularly spaced into two rows, or peripheral cycles, with offset between the spines of the two cycles. The regularity of the spine spacing and the limitation to two parallel cycles distinguishes $M$. circulus var. apiculata from $M$. circulus and $M$. dumitricae. Some variants with knobby spines or small nodes are illustrated.

\section{Mesocena diodon borderlandensis Bukry}

(Plate 4, Fig. 1)

Mesocena diodon borderlandensis Bukry, 1981, p. 547, pl. 4, figs. 5-9; pl. 5 , figs. 1,2 .

Remarks. Only two compared specimens of Mesocena diodon borderlandensis were found among the abundant Mesocena at Site 594 The elongate morphology of $M$. diodon borderlandensis is most prominent at Site 469, off California, in the lower upper Miocene.

\section{Mesocena diodon nodosa Bukry}

(Plate 4, Figs. 2-6)

Mesocena diodon nodosa Bukry, 1978 (in part), p. 818, pl. 5, figs. 14, 15; pl. 6, figs. 1-3 (not figs. 4, 5 which are now classified as Mesocena diodon borderlandensis Bukry).

Mesocena diodon nodosa Bukry, Bukry and Monechi, in press, pl. 9, figs. $1-3$; pl. 16, fig. 4 .

Remarks. The most abundant populations of Mesocena diodon nodosa occur in the middle and upper Miocene. Aside from the normal specimens with prolate elliptic rings, two minor varieties that are circular or oblate were also found and recorded at Site 594. The circular variety is most common (14\%) in Sample 594-28-5, 8-9 cm, whereas the oblate is most common (3\%) just below in Sample 594-29-2, $8-9 \mathrm{~cm}$.

Mesocena dumitricae (Perch-Nielsen) emend. Bukry, n. comb. (Plate 5, Figs. 1, 2)

Mesocena circulus Ehrenberg, Ling, 1972 (in part), p. 175, pl. 28, figs. 5,6 .

Mesocena circulus Ehrenberg, Stadum and Burckle, 1973, p. 108, pl. 1, figs. 1-5.

Mesocena circulus Ehrenberg, Ciesielski, 1975, p. 661, pl. 11, figs. 6 , $8,9$.

Mesocena circulus (Ehrenberg), Bukry, 1975a (in part), p. 718, pl. 2 fig. 5.

Paradictyocha dumitricae Perch-Nielsen, 1975, p. 689, pl. 11, figs. 1 , 5-8.

Mesocena circulus Ehrenberg, Busen and Wise, 1977, p. 715, pl. 7, figs. 2, 3, 4? 6 ?; pl. 11, figs. 1,2 .

Remarks. Mesocena dumitricae was described as having a polygonal rather than round outline (Perch-Nielsen, 1975); however, four of the five type specimens show nearly continuous curvature around the ring. Also, the spines were characterized as short, but moderate to moderately long spines are also known in populations from different areas (see Stadum and Burckle, 1973; and Bukry, 1975a, c). The most diagnostic features of $M$. dumitricae, as emended herein, are the single cycle of regularly spaced equant spines which lie in the plane of the ring. Specimens of $M$. dumitricae with polygonal and essentially circular rings may occur together (Perch-Nielsen, 1975, pl. 11).

Occurrence. Mesocena dumitricae emend. has previously been tabulated as $M$. circulus, so the full stratigraphic and geographic range are not known, but the illustrations of high-latitude Mesocena by Busen and Wise (1977) and Stadum and Burckle (1973) suggest that $M$. dumitricae may favor cooler areas where upwelling is strong.

\section{Mesocena quadrangula Ehrenberg ex Haeckel (Plate 5, Fig. 3)}

Mesocena quadrangula Ehrenberg ex Haeckel, 1887, p. 1556.

Mesocena quadrangula Ehrenberg ex Haeckel, Bukry, 1979, p. 574, pl. 5, figs. 5, 6 .

Remarks. Mesocena quadrangula is largely missing from the assemblages at Site 594. Sparse specimens occur only in two samples from Cores 21 and 23 near the top of the silicoflagellate-bearing section. The conjunction of $M$. quadrangula and $M$. triangula in Core 23 suggests a correlation to the upper part of Site 329 , which is considered upper Miocene.

\section{Mesocena triangula (Ehrenberg)}

(Plate 5, Figs. 3-6)

Dictyocha triangula Ehrenberg, 1839, p. 129. Figured by Ehrenberg, 1854 , pl. 22, fig. 41 
Mesocena triangula (Ehrenberg) Ehrenberg, 1844, p. 65, 71.

Mesocena triangula (Ehrenberg), Bukry and Foster, 1973 (in part), p. 829, pl. 6 , figs. 9,10 .

Mesocena triangula (Ehrenberg), Ling, 1977, p. 214, pl. 3, fig. 6.

Remarks. Mesocena triangula has surface texture and stratigraphic distribution which suggest derivation from Mesocena quadrangula or possibly $M$. circulus. A triangular variant of $M$. diodon nodosa from Site 594 (Plate 4, Figs. 5, 6) shows distinctive crenulate surface texture suggesting different affinities than $M$. triangula at Site 594 .

Occurrence. The highest abundances reported for Mesocena triangula are $8 \%$ at Site 555 in the North Atlantic and $9 \%$ at Site 594 in the South Pacific. Both are in late Miocene samples. Infrequent occurrences in other areas are typically 1 or $2 \%$ in assemblages from Oligocene (Busen and Wise, 1977) to Quaternary (Bukry, 1975c). This long range supports polyphyletic or secondary origins for many of the occurrences of the species. But the late Miocene occurrences at Site 594, 555 , and 329 show a potential correlation between the Dictyocha brevispina Zone and Distephanus speculum Zone. Because M. triangula occurs in cool $(\mathrm{Ts}=2)$ to relatively warm $(\mathrm{Ts}=42)$ assemblages no single temperature regime seems responsible for its occurrence.

\section{Mesocena triodon Bukry}

Mesocena triodon Bukry, 1973a, p. 860, pl. 2, fig. 11. Mesocena triodon Bukry, Bukry, 1978, p. 819, pl. 7, figs. 9, 10.

Remarks. The occurrence of rare specimens of Mesocena triodon at Site 594, in assemblages lacking $M$. quadrangula, indicates that $M$. triodon is more closely related to $M$. diodon nodosa than to $M$. quadrangula.

\section{OTHER TAXA CITED}

\section{Silicoflagellates}

Bachmannocena Locker

Caryocha Bukry and Monechi

Corbisema apiculata (Lemmermann) Hanna

C. disymmetrica angulata Bukry

C. glezerae Bukry

C. hastata globulata Bukry

C. hastata hastata (Lemmermann) Frenguelli

C. inermis (Lemmermann) Dumitricà

C. triacantha (Ehrenberg) Hanna

Dictyocha aspera aspera (Lemmermann) Frenguelli

D. aspera clinata Bukry

D. brevispina (Lemmermann) Bukry

D. deflandrei completa (Glezer) Bukry

D. fibula augusta Bukry

D. fibula fibula Ehrenberg

D. pentagona (Schulz) Bukry and Foster

D. pulchella Bukry

D. pulchella var. inflata Bukry

Distephanus crux crux (Ehrenberg) Haeckel

D. frugalis (Bukry) Bukry

D. octangulatus Wailes

D. octonarius (Ehrenberg) Haeckel

D. polyactis crassus Bukry

D. pseudofibula (Schulz) Bukry

D. quinquangellus Bukry and Foster

D. speculum diommata (Ehrenberg) Bukry

D. speculum minutus (Bachmann) emend. Bukry

D. speculum speculum (Ehrenberg) Haeckel

D. speculum triommata (Ehrenberg) Bukry

D. varians (Gran and Braarud) Bukry

D. xenus Bukry

Mesocena apiculata apiculata (Schulz) Hanna

M. apiculata curvata Bukry

M. apiculata glabra (Schulz) Bukry

Naviculopsis aspera (Schulz) Perch-Nielsen

$N$. biapiculata (Lemmermann) Frenguelli

N. constricta (Schulz) emend. Bukry

N. eobiapiculata Bukry

N. trispinosa (Schulz) Glezer

Octactis Schiller

Paradictyocha Frenguelli

Septamesocena Bachmann

\section{Diatoms}

Rocella gelida (Mann) Bukry

R. schraderi Bukry

\section{Coccoliths}

Amaurolithus tricorniculatus (Gartner) Gartner and Bukry Chiasmolithus oamaruensis (Deflandre) Hay et al.

Discoaster bellus Bukry and Percival

$D$. brouweri Tan, emend. Bramlette and Riedel

D. hamatus Martini and Bramlette

D. kugleri Martini and Bramlette

D. quinqueramus Gartner

Isthmolithus recurvus Deflandre

Triquetrorhabdulus rugosus Bramlette and Wilcoxon

\section{ACKNOWLEDGMENTS}

I thank Jack G. Baldaulf and John A. Barron, U.S. Geological Survey, Menlo Park, for their helpful reviews and comments. John A. Barron provided valuable diatom correlations to assist in time-slice comparisons of relative paleotemperature values. The manuscript was typed and proofed with usual thoroughness and aplomb by Dorothy L. Blackstock, U.S. Geological Survey, La Jolla.

\section{REFERENCES}

Bukry, D., 1973a. Coccoliths and silicoflagellates from Deep Sea Drilling Project Leg 19, North Pacific Ocean and Bering Sea. In Creager, J. S., Scholl, D. W., et al., Init. Repts. DSDP, 19: Washington (U.S. Govt. Printing Office), 857-867.

1973b. Coccolith and silicoflagellate stratigraphy, Deep Sea Drilling Project Leg 18, eastern North Pacific. In Kulm, L. D., von Huene, R., et al., Init. Repts. DSDP, 18: Washington (U.S. Govt. Printing Office), 817-831.

,1975a. Coccolith and silicoflagellate stratigraphy near Antarctica, Deep Sea Drilling Project Leg 28. In Hayes, D. E., Frakes, L. A., et al., Init. Repts. DSDP, 28: Washington (U.S. Govt. Printing Office), 709-723.

1975b. Phytoplankton stratigraphy, southwest Pacific, Deep Sea Drilling Project Leg 30. In Andrews, J. E., Packham, G., et al., Init. Repts. DSDP, 30: Washington (U.S. Govt. Printing Office), 539-547.

1975c. Silicoflagellate and coccolith stratigraphy, Deep Sea Drilling Project Leg 29. In Kennett, J. P., Houtz, R. E., et al., Init. Repts. DSDP, 29: Washington (U.S. Govt. Printing Office), 845-872.

1976a. Cenozoic silicoflagellate and coccolith stratigraphy, South Atlantic Ocean, Deep Sea Drilling Project Leg 36. In Hollister, C. D., Craddock, C., et al., Init. Repts. DSDP, 35: Washington (U.S. Govt. Printing Office), 885-917.

1976b. Comments on some coccoliths and silicoflagellates from Deep Sea Drilling Project Leg 35. In Hollister, C. D., Craddock, C., et al., Init. Repts. DSDP, 35: Washington (U.S. Govt. Printing Office), 693-699.

1978. Cenozoic coccolith, silicoflagellate, and diatom stratigraphy, Deep Sea Drilling Project Leg 44. In Benson, W. E., Sheridan, R. E., et al., Init. Repts. DSDP, 44: Washington (U.S. Govt. Printing Office), 807-863.

1979. Coccolith and silicoflagellate stratigraphy, northern Mid-Atlantic Ridge and Reykjanes Ridge, Deep Sea Drilling Project Leg 49. In Luyendyk, B. P., Cann, J. R., et al., Init. Repts. DSDP, 49: Washington (U.S. Govt. Printing Office), 551-581.

1981. Silicoflagellate stratigraphy of offshore California and Baja California, Deep Sea Drilling Project Leg 63. In Yeats, R. S., Haq, B. U., et al., Init. Repts. DSDP, 63: Washington (U.S. Govt. Printing Office), 539-557.

1983. Upper Cenozoic silicoflagellates from offshore Ecuador, Deep Sea Drilling Project Site 504. In Cann, J. R., Langseth, M. G., et al., Init. Repts. DSDP, 69: Washington (U.S. Govt. Printing Office), 321-342.

1984. Cenozoic silicoflagellates from Rockall Plateau, Deep Sea Drilling Project Leg 81. In Roberts, D. G., Schnitker, D., et al., Init. Repts. DSDP, 81: Washington (U.S. Govt. Printing Office) $547-563$.

, in press. Tropical Pacific Pacific silicoflagellate zonation and paleotemperature trends of the Late Cenozoic. In Mayer, L., They- 
er, F., et al., Init. Repts. DSDP, 85: Washington (U.S. Govt. Printing Office).

Bukry, D., and Foster, J. H., 1973. Silicoflagellate and diatom stratigraphy, Leg 16, Deep Sea Drilling Project. In van Andel, T. H., Heath, G. R., et al., Init. Repts. DSDP, 16: Washington (U.S. Govt. Printing Office), 815-871.

Bukry, D., and Kennedy, M. P., 1969. Cretaceous and Eocene coccoliths at San Diego, California. Calif. Div. Min. Geol. Spec. Rept., 100:33-43.

Bukry, D., and Monechi, S., in press. Late Cenozoic silicoflagellates from the Northwest Pacific, Deep Sea Drilling Project Leg 86: Paleotemperature trends and texture Classification. In Heath, G. R., Burckle, L. H., et al., Init. Repts. DSDP, 86: Washington (U.S. Govt. Printing Office).

Burkov, V. A., 1966. Structure and nomenclature of Pacific Ocean currents. Oceanology, 6:1-10.

Busen, K. E., and Wise, S. W., Jr., 1977. Silicoflagellate stratigraphy, Deep Sea Drilling Project, Leg 36. In Barker, P., Dalziel, I. W. D., et al., Init. Repts. DSDP, 36: Washington (U.S. Govt. Printing Office), 697-743.

Ciesielski, P. F., 1975. Biostratigraphy and paleoecology of Neogene and Oligocene silicoflagellates from cores recovered during Antarctic Leg 28, Deep Sea Drilling Project. In Hayes, D. E., Frakes, L. A., et al., Init. Repts. DSDP, 28: Washington (U.S. Govt. Printing Office), 625-691.

Csanady, G. T., 1984. Warm water mass formation. J. Phys. Oceanogr., $14: 264-275$.

Dumitrič̆, P., 1973. Paleocene, late Oligocene and post-Oligocene silicoflagellates in southwestern Pacific sediments cored on DSDP Leg 21. In Burns, R. E., Andrews, J. E., et al., Init. Repts. DSDP, 21: Washington (U.S. Govt. Printing Office), 837-883.

Ehrenberg, C. G., 1839. Über die Bildung der Kreidefelsen und des Kreidemergels durch unsichtbare Organismen. K. Akad. Wiss. Berlin, Abh., Jahr. 1838 (1840, separate 1839):59-148.

, 1840. Blätter von ihm selbst ausgeführter Zeichnungen von ebenso vielen Arten. K. Preuss. Akad. Wiss. Berlin Ber., Jahr. 1840:197-219 (Nov.)

1844. Untersuchungen über die kleinsten Lebensformen im Quellenlande des Euphrats und Araxes, so wie über eine an neuen Formen sehr reiche marine Tripelbildung von den Bermuda-Inseln vor. K. Preuss. Akad. Wiss. Berlin Ber., Jahr. 1844:253-275. 1854. Mikrogeologie: Leipzig (Leopold Voss), 1-374.

Haeckel, E. H. P. A., 1887, Cannorrhaphida. Challenger Rept. 18: 1546-1569.

Haq, B. U., and Riley, A., 1976. Antarctic silicoflagellates from the southeast Pacific, Deep Sea Drilling Project Leg 35. In Hollister, C. D., Craddock, C., et al., Init. Repts. DSDP, 35: Washington (U.S. Govt. Printing Office), 673-691.

Keller, G., 1981. Miocene biochronology and paleoceanography of the North Pacific. Mar. Micropaleontol., 6:535-551.
Kennett, J. P., 1980. Paleoceanographic and biogeographic evolution of the Southern Ocean during the Cenozoic, and Cenozoic microfossil datums. Palaeogeogr., Palaeoclimatol., Palaeoecol., 31: 123-152.

Lemmermann, E., 1901. Silicoflagellatae. Ber. Dtsch. Bot. Ges., 19: 247-271.

Ling, H. Y., 1972. Upper Cretaceous and Cenozoic silicoflagellates and ebridians. Bull. Am. Paleontology, 62:135-229.

1977. Late Cenozoic silicoflagellates and ebridians from the eastern North Pacific region. Proc. Ist Int. Congr. Pacific Neogene Stratigraphy, Tokyo, 205-233.

1980. Silicoflagellates and ebridians from Leg 55. In Jackson, E. D., Koizumi, I., et al., Init. Repts. DSDP, 55: Washington (U.S. Govt. Printing Office), 375-385.

Locker, S., 1974. Revision der Silicoflagellaten aus der Mikrogeologischen Sammlung von C. G. Ehrenberg. Eclog. Geol. Helv., 67: 631-646.

Loeblich, A. R., III, Loeblich, L. A., Tappan, H., and Loeblich, A. R. Jr., 1968. Annotated index of fossil and recent silicoflagellates and ebridians with descriptions and illustrations of validly proposed taxa. Mem. Geol. Soc. Am., 106:1-319.

Mandra, Y. T., Brigger, A. L., and Mandra, H., 1973. Preliminary report on a study of fossil silicoflagellates from Oamaru, New Zealand. Occas. Pap. Calif. Acad. Sci., 107:1-11.

Mandra, Y. T., and Mandra, H., 1972. Paleoecology and taxonomy of silicoflagellates from an upper Miocene diatomite near San Felipe, Baja California, Mexico. Occas. Pap., Calif. Acad. Sci., 99:1-35.

Martini, E., 1971. Standard Tertiary and Quaternary calcareous nannoplankton zonation. In Farinacci, A. (Ed.), Proc. 2nd Planktonic Conf., Roma: Rome (Edizioni Tecnoscienza), 739-785.

Martini, E., and Müller, C., 1976. Eocene to Pleistocene silicoflagellates from the Norwegian-Greenland Sea (DSDP Leg 38). In Talwani, M., Edintsev, G., et al., Init. Repts. DSDP, 38: Washington (U.S. Govt. Printing Office), 857-895.

Perch-Nielsen, K., 1975. Late Cretaceous to Pleistocene archaemonads, ebridians, endoskeletal dinoflagellates, and other siliceous microfossils from the subantarctic southwest Pacific, DSDP Leg 29. In Kennett, J. P., Houtz, R. E., et al., Init. Repts. DSDP, 29: Washington (U.S. Govt. Printing Office), 873-907.

Stadum, C. J., and Burckle, L. H., 1973. A silicoflagellate ooze from the east Falkland Plateau. Micropaleontology, 19:104-109.

Stradner, H., and Bachmann, A., 1978. Late Pliocene and early Pleistocene silicoflagellates and ebridians from DSDP Site 378 in the Aegean Basin, north of Crete. In Hsü, K. J., Montadert, L., et al., Init. Repts. DSDP, 42, Pt. 1: Washington (U.S. Govt. Printing Office), 805-815.

Date of Initial Receipt: 24 August 1984

Date of Acceptance: 8 September 1984 

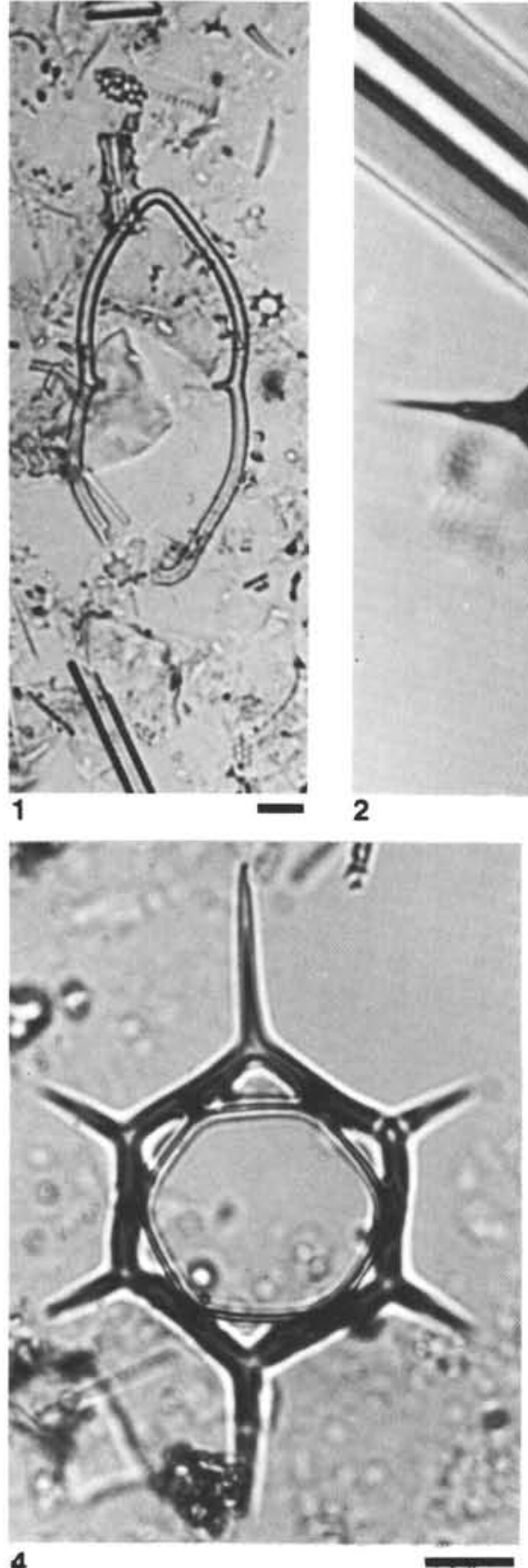
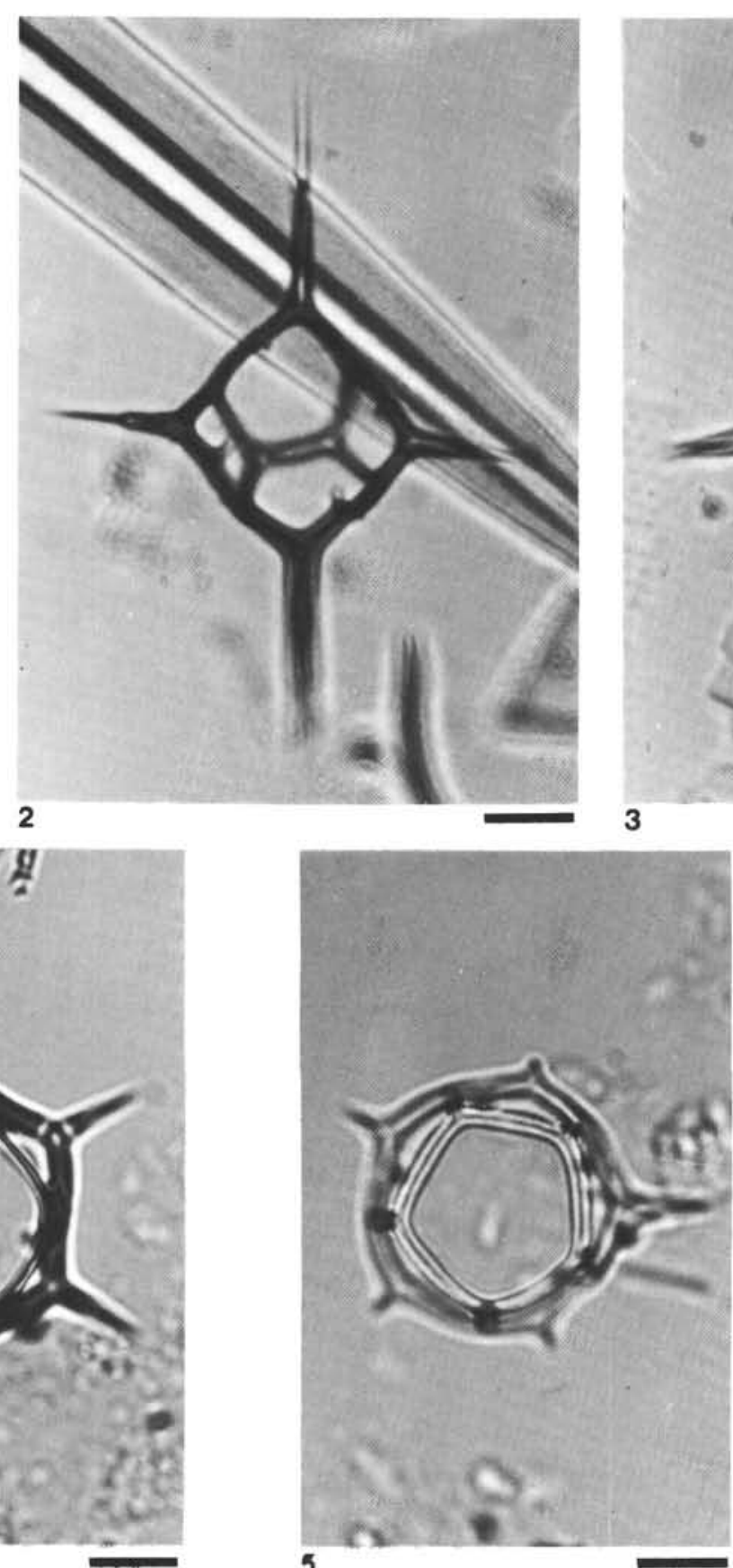

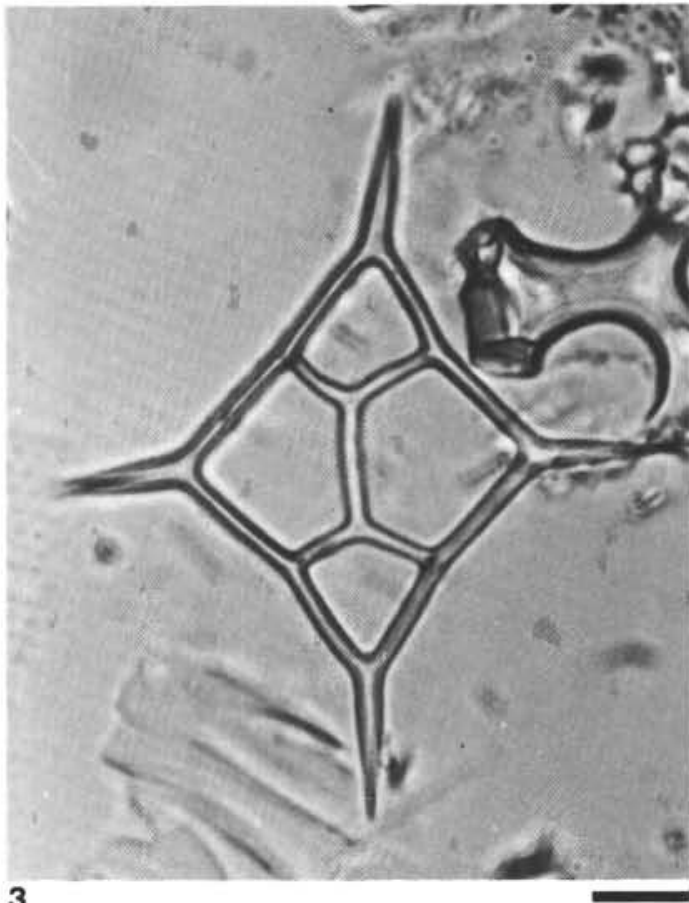

3

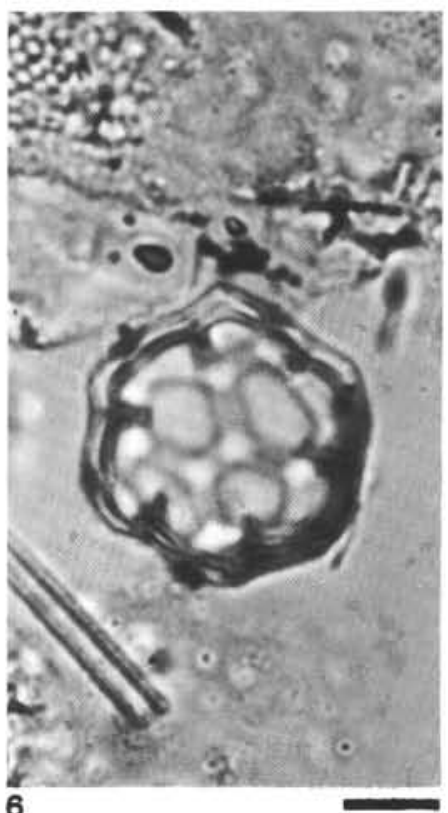

Plate 1. Silicoflagellates from DSDP Leg 90. (Scale bar equals $10 \mu \mathrm{m}$.) 1. Corbisema sp; compare Corbisema disymmetrica angulata Bukry, Sample 594-31-2, 8-9 cm. 2. Dictyocha aspera clinata Bukry s. ampl., Sample 594-27-2, 8-9 cm. 3. Dictyocha fibula augusta Bukry, Sample 594-27-2, 8-9 cm. 4, 5. Distephanus speculum minutus (Bachmann), Sample 594-20-2, 8-9 cm, (4) normal specimen, (5) pentagonal variant. 6. Distephanus xenus Bukry, Sample $594-21-2,8-9 \mathrm{~cm}$; basal focus. 

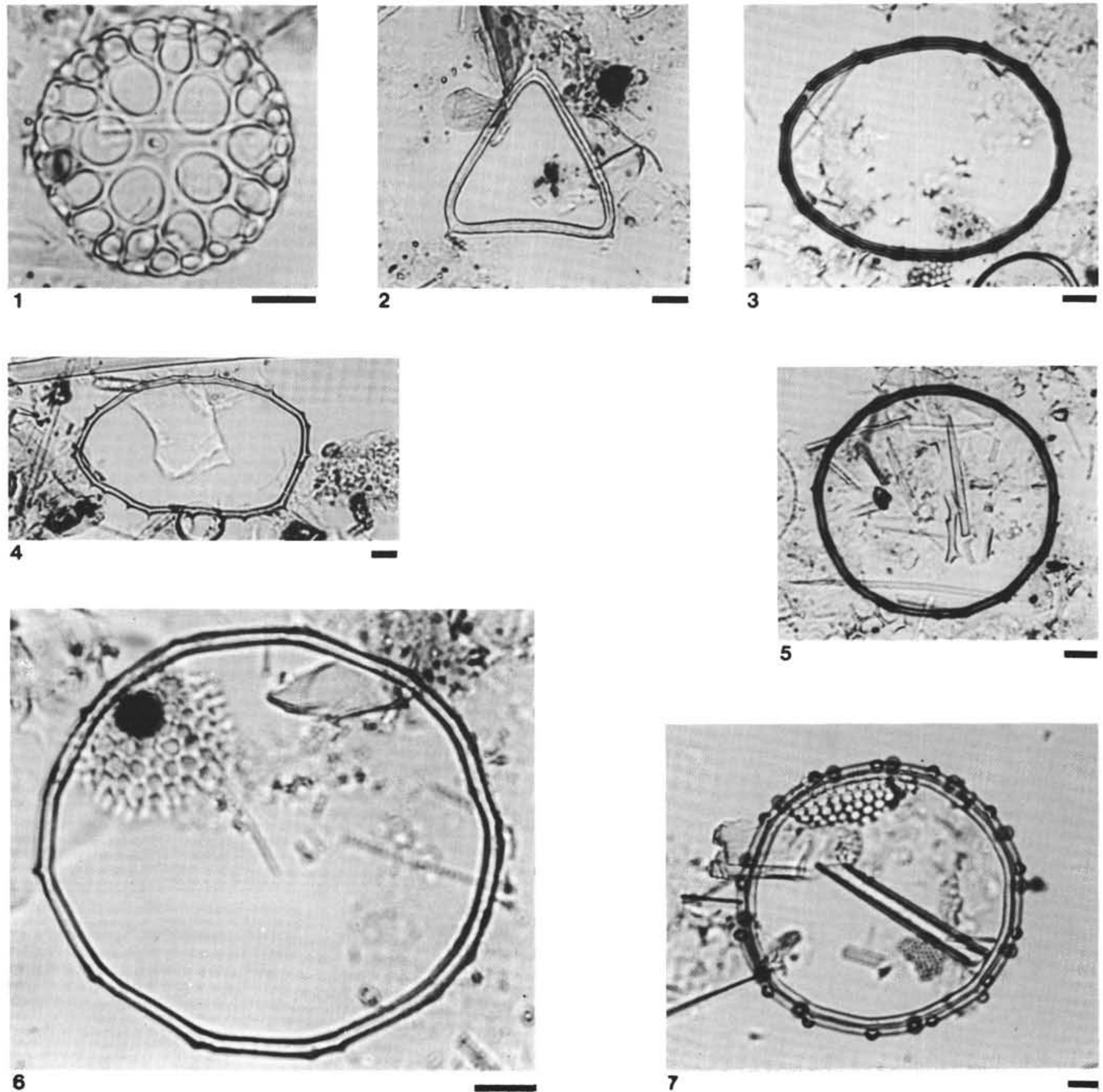

Plate 2. Diatom and silicoflagellates from DSDP Leg 90. (Scale bar equals $10 \mu \mathrm{m}$.) 1. Rocella schraderi Bukry, Sample 594-31-2, 8-9 cm (diatom). 2. Mesocena apiculata curvata Bukry, Sample 594-48-2, 8-9 cm. 3-7. Mesocena circulus var. apiculata Lemmermann, (3) elliptic, Sample 594-31-2, 8-9 cm, (4) oblong, Sample 594-47-1, 8-9 cm, $(5,6)$ circular and nearly spineless, Sample 594-31-2, 8-9 cm, (7) knobby variant, Sample 594-30-2, 8-9 cm. 

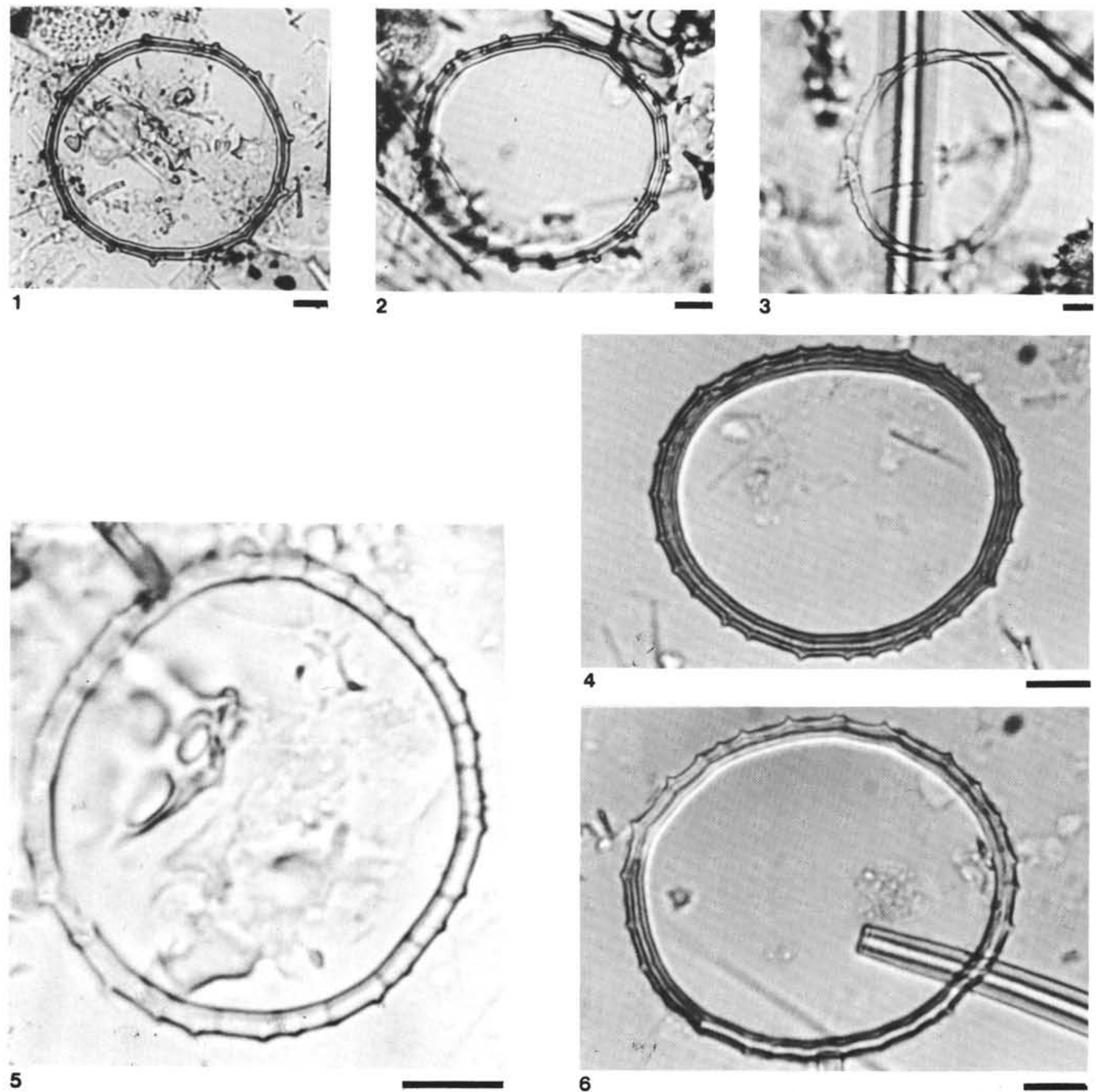

Plate 3. Silicoflagellates from DSDP Leg 90. (Scale bar equals $10 \mu \mathrm{m}$.) 1, 2. Mesocena circulus var. apiculata Lemmermann, knobby variant, (1) Sample 594-31-2, 8-9 cm, (2) Sample 594-30-2, 8-9 cm. 3-6. Mesocena circulus (Ehrenberg), (3) Sample 594-27-2, 8-9 cm, (4, 5) verticillate nodes suggest affinities with Mesocena diodon nodosa; Sample 594-25-2, 8-9 cm, (6) Sample 594-25-2, 8-9 cm. 

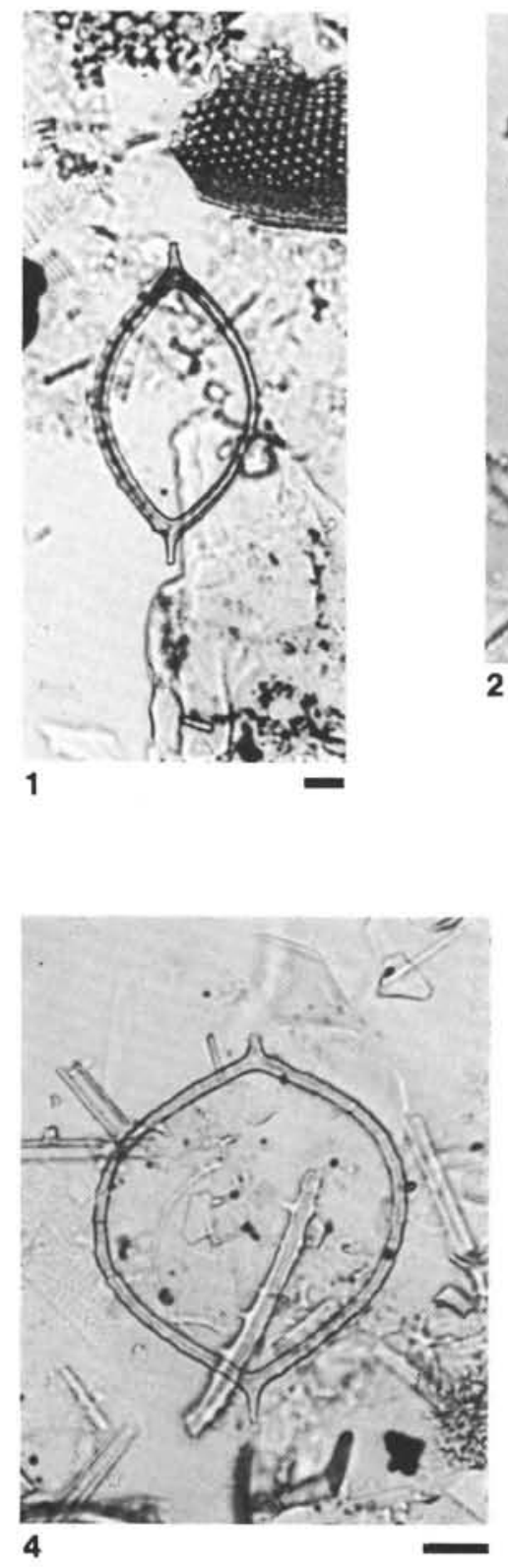
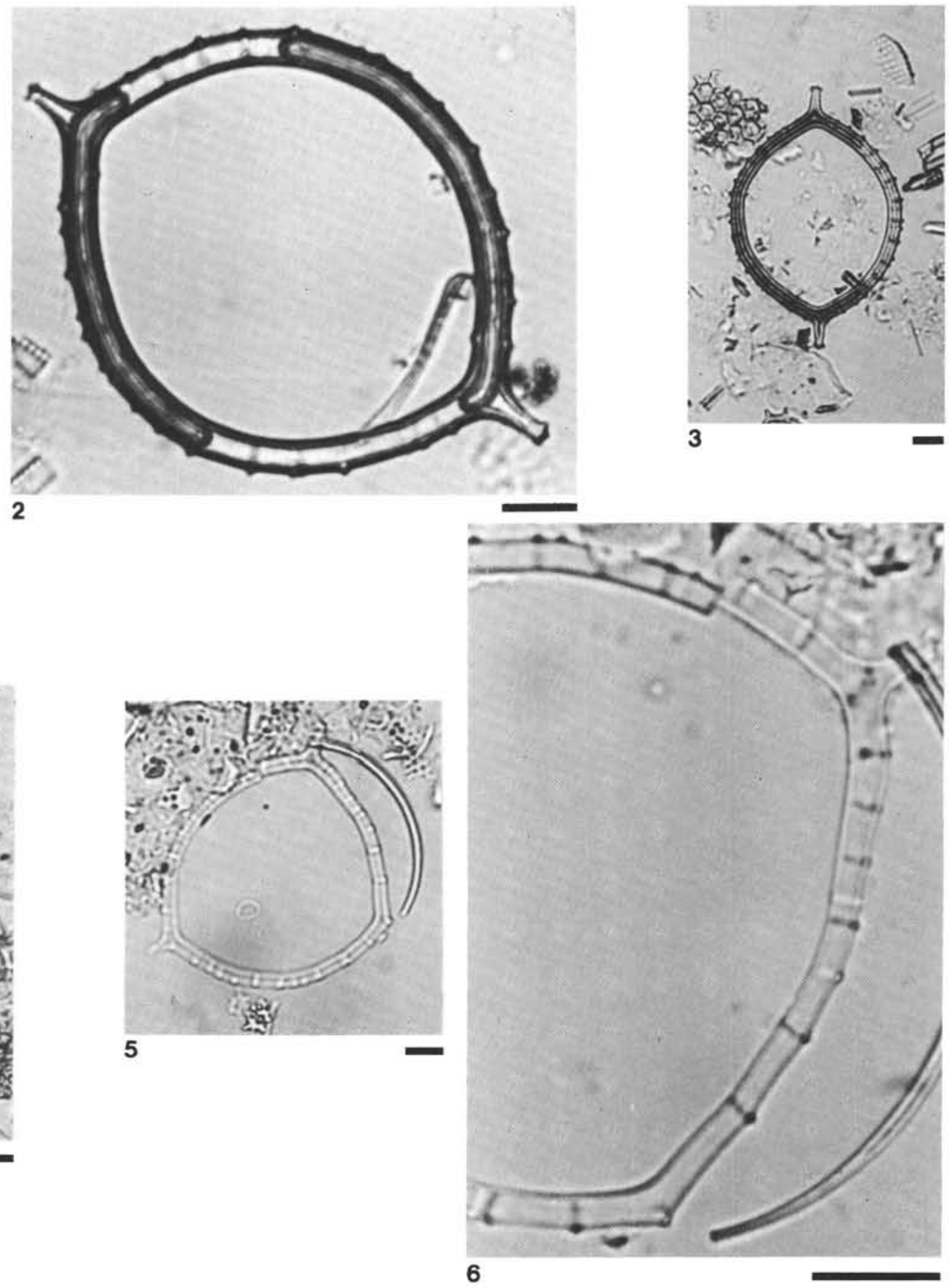

Plate 4. Silicoflagellates from DSDP Leg 90. (Scale bar equals $10 \mu \mathrm{m}$.) 1. Mesocena sp. cf. $M$. diodon borderlandensis Bukry, Sample 594-27-2, 8-9 cm. 2-6. Mesocena diodon nodosa Bukry, (2) Sample 594-30-2, 8-9 cm, (3) Sample 594-27-2, 8-9 cm, (4) oblate, Sample 594-23-5, 8-9 cm, $(5,6)$ triangular variant, Sample 594-23-5, 8-9 cm. 

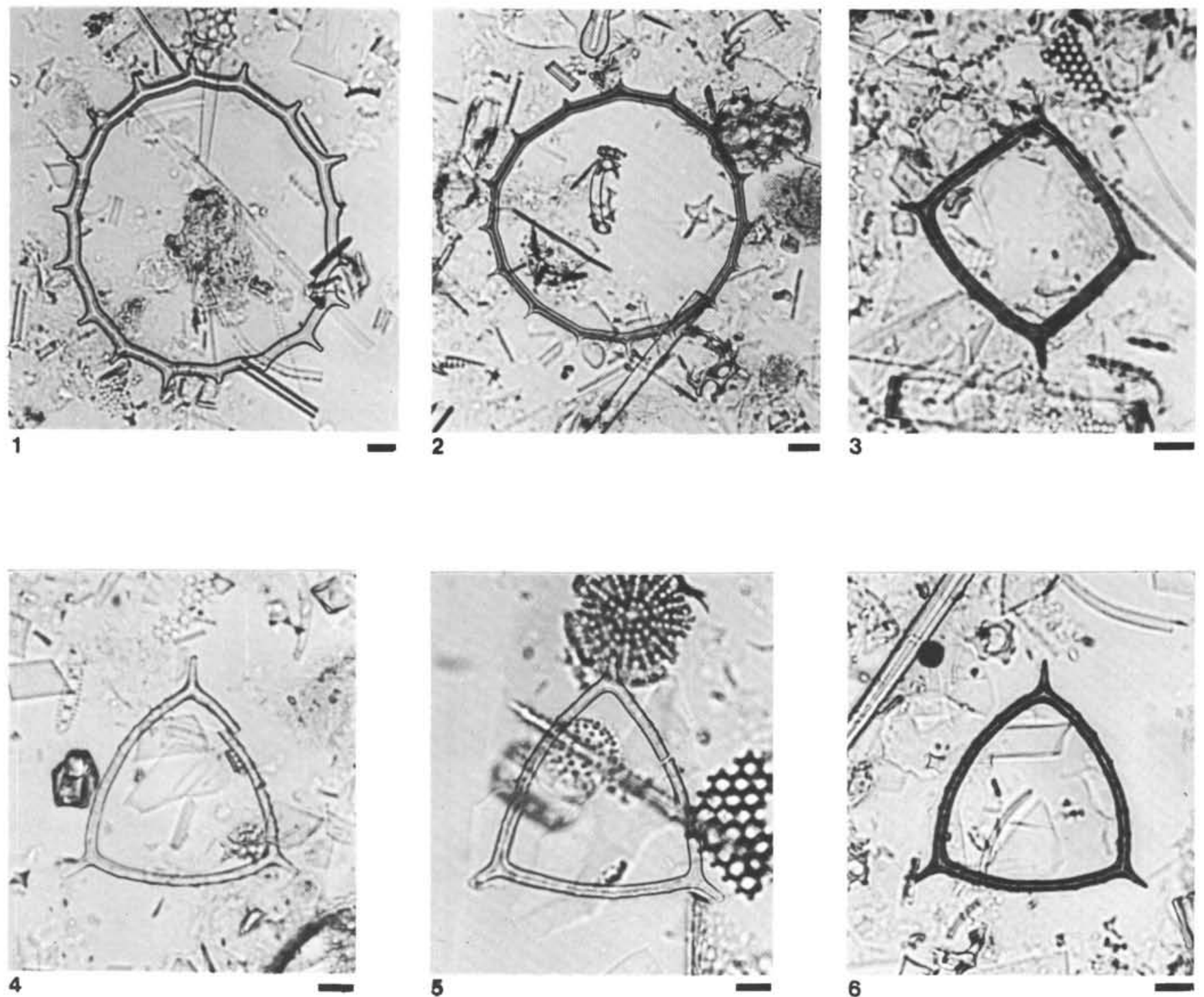

Plate 5. Silicoflagellates from DSDP Leg 90. (Scale bar equals $10 \mu \mathrm{m}$.) 1, 2. Mesocena dumitricae (Perch-Nielsen), Sample 594-27-2, 8-9 cm. 3. Mesocena quadrangula Ehrenberg ex Haeckel, Sample 594-23-5, 8-9 cm. 4-6. Mesocena triangula (Ehrenberg), Sample 594-23-5, 8-9 cm. 